\title{
Genetic testing for vascular anomalies
}

\author{
Stefano Paolacci ${ }^{1}$, Yeltay Rakhmanov ${ }^{2}$, Paolo Enrico Maltese ${ }^{2 \star}$, Francesca Fanelli ${ }^{1}$, Raul Ettore Mattassi ${ }^{3}$, \\ Bruno Amato ${ }^{4}$ and Matteo Bertelli ${ }^{1,2}$
}

\begin{abstract}
Vascular anomalies (VAs) have phenotypic variability within the same entity, overlapping clinical features between different conditions, allelic and locus heterogeneity and the same disorder can be inherited in different ways. Most VAs are sporadic (paradominant inheritance or de novo somatic or germline mutations), but hereditary forms (autosomal dominant or recessive) have been described. This Utility Gene Test was developed on the basis of an analysis of the literature and existing diagnostic protocols. The genetic test is useful for confirming diagnosis, as well as for differential diagnosis, couple risk assessment and access to clinical trials.
\end{abstract}

Keywords: Vascular anomalies, germline mutations, somatic mutations, EBTNA UTILITY GENE TEST

${ }^{1}$ MAGI Euregio, Bolzano, Italy

${ }^{2}$ MAGI's Lab, Rovereto, Italy

${ }^{3}$ Center for Vascular Malformations, "Stefan Belov", Clinical Institute Humanitas "Mater Domini", Castellanza (Varese), Italy

${ }^{4}$ Department of Clinical Medicine and Surgery at University of Naples Federico II, Naples, Italy

*Corresponding author: P. E. Maltese E-mail: paolo.maltese@assomagi.org

DOI: $10.2478 / \mathrm{ebtj}-2018-0030$

\section{Vascular anomalies}

(Other synonyms: Vascular anomalies are a group of diseases; see phenotypic variants)

\section{General information about the disease}

Vascular anomalies (VAs) combine an extremely heterogeneous group of congenital abnormalities of the vascular system. VAs include vascular tumours, such as hemangioma, and malformations of veins, arteries, capillaries and the lymphatic system. Anomalies may occur during embryogenesis. They may be morphological, structural and/or functional defects affecting different types and calibers of vessels in any anatomical area (1). When more than one type of vessel is affected, the term mixed anomaly is used. Vascular anomalies can also occur in the context of syndromes (2). Disorders characterized by VAs have phenotypic variability within the same entity, overlapping clinical features between different conditions, allelic and locus heterogeneity, and the same disorder can be inherited in different ways. Although most vascular anomalies are sporadic (paradominant inheritance or de novo somatic mutations), there are well-described syndromic and hereditary forms of VAs (autosomal dominant or recessive). VAs have high clinical variability: indeed they may manifest as monofocal or multifocal lesions and they may be congenital or appear/develop later $(3,4)$.

Prevalence is unknown.

Diagnostic work-up may include clinical history, clinical examination, vascular echoDoppler and vascular magnetic resonance imaging.

Vascular anomalies can be classified on the basis of the vessels affected:

\section{Vascular tumours}

- Capillary infantile hemangioma (OMIM disease 602089) can be sporadic or have autosomal dominant inheritance. It can be caused either by somatic mutations in $K D R$, 
FLT4 (OMIM gene 136352), DUSP5 (OMIM gene 603069), GNAQ (OMIM gene 600998), GNA11 (OMIM gene 39313) or GNA14 (OMIM gene 604397) or by germline mutations in ANTXR1 (OMIM gene 606410) or KDR (OMIM gene 191306) (5-8).

- Verrucous venous malformation (OMIM disease not available) is sporadic and is caused by somatic mutations in MAP3K3 (OMIM gene 602539) (9).

- Pyogenic granuloma (OMIM disease not available) is sporadic and is caused by somatic mutations in BRAF, NRAS or KRAS (10)

\section{Venous malformations}

- Multiple cutaneous and mucosal venous malformations (VMCM, OMIM disease 600195) can be caused either by mutations in TEK (OMIM gene 600221) with dominant or paradominant inheritance, or by sporadic somatic mutations in PIK3CA (OMIM gene 171834) $(11,12)$.

- Glomuvenous malformations (GVM, OMIM disease 138000) can have dominant or paradominant inheritance and are caused by mutations in GLMN (OMIM gene 601749) (13).

- Cerebral cavernous malformations type 1 (CCM1, OMIM disease 116860), type 2 (CCM2, OMIM disease 603284) and type 3 (CCM3, OMIM disease 603285) have dominant or paradominant inheritance and are caused by mutations in KRIT1 (OMIM gene 604214), CCM2 (OMIM gene 607929) and PDCD10 (OMIM gene 609118), respectively (14-16).

- Blue rubber bleb nevus syndrome (OMIM disease 12200) is sporadic and is caused by somatic mutations in TEK (17).

\section{Capillary malformations}

- Congenital capillary malformations (CMC, OMIM disease 163000) are sporadic and are caused by somatic mutations in GNAQ or GNA11 $(18,19)$.

- Parkes Weber syndrome (PKWS, OMIM disease 608355) has dominant or paradominant inheritance and is caused by mutations in RASA1 (OMIM gene 139150) (20).

- Sturge-Weber syndrome (SWS, OMIM 185300) is sporadic and is caused by somatic mutations in GNAQ (21).

- Capillary malformations-arteriovenous malformations (CMAVM, OMIM 608354) can be sporadic or have dominant inheritance and are caused either by somatic mutations in RASA1 or by germline mutations in RASA1 or EPHB4 (OMIM gene 600011) $(20,22)$.

- Hereditary hemorrhagic telangiectasia type 1 (HHT1, OMIM disease 187300) and type 2 (HHT2, OMIM disease 600376) have dominant or paradominant inheritance and are caused by mutations in ENG (OMIM gene 131195) and ACVRL1 (OMIM gene 601284), respectively. Hereditary hemorrhagic telangiectasia type 5 (HHT5, OMIM disease 615506) has autosomal dominant inheritance. It is caused by mutations in GDF2 (OMIM gene 605120). Pathogenic mutations in RASA1 have been reported in patients with a form of dominant hereditary hemorrhagic telangiectasia
$(23,24)$.

- Juvenile polyposis/hereditary hemorrhagic telangiectasia syndrome (JPHT, OMIM disease 175050) has autosomal dominant inheritance. It is caused by mutations in SMAD4 (OMIM gene 600993) (25).

\section{Syndromic arteriovenous anomalies}

- Klippel-Trénauny-Weber syndrome (OMIM disease 149000) and congenital lipomatous overgrowth, vascular malformations and epidermal nevi syndrome (CLOVES, OMIM disease 612918) are sporadic and are caused by somatic mutations in PIK3CA (26).

- Multiple enchondromatosis, Maffucci type (OMIM disease $614569)$ is sporadic and is caused by somatic mutations in IDH1 (OMIM gene 147700) and IDH2 (OMIM gene 147650) (27).

- Proteus syndrome (OMIM disease 176920) is sporadic and is caused by somatic mutations in AKT1 (OMIM gene 164730) (28).

- Loeys-Dietz syndrome type 1 (OMIM disease 609192), type 2 (OMIM disease 600168), type 3 (OMIM disease 613795) and type 4 (OMIM disease 614816) have autosomal dominant inheritance. They are caused by mutations in TGFBR1 (OMIM gene 606145), TGFBR2 (OMIM gene 190182), SMAD3 (OMIM gene 603109) and TGFB2 (OMIM gene 190220), respectively (29-31).

- Ehlers-Danlos syndrome, vascular type (EDSVASC, OMIM disease 130050) has autosomal dominant inheritance. It is caused by mutations in COL3A1 (OMIM gene 120180) (32).

- Arterial tortuosity syndrome (ATS, OMIM disease 208050) has autosomal recessive inheritance. It is caused by mutations in SLC2A10 (OMIM gene 606145) (33).

- Cowden syndrome type 1 (CWS1, OMIM disease 158350), type 5 (CWS5, OMIM disease 615108) and type 6 (CWS6, OMIM disease 615109) have autosomal dominant inheritance. They are caused by mutations in PTEN (OMIM gene 601728), PIK3CA, and AKT1, respectively $(34,35)$.

- Marfan syndrome (MFS, OMIM disease 154700) has autosomal dominant inheritance. It is caused by mutations in FBN1 (OMIM gene 134797) (36).

- Pseudoxanthoma elasticum (PXE, OMIM disease 264800) has autosomal recessive inheritance. It is caused by mutations in ABCC6 (OMIM gene 603234) and ENPP1 (OMIM gene 173335) (37).

- Microcephaly-capillary malformation syndrome; (MICCAP, OMIM disease 614261) has autosomal recessive inheritance. It is caused by mutations in STAMBP (OMIM gene 606247) (38).

Recently, somatic mutations in MAP2K1 (OMIM gene 176872) were found in patients with sporadic extracranial arteriovenous malformations (39), and germline mutations in ELMO2 (OMIM gene 606421) were found in patients with intraosseous vascular malformations (it is unclear if this malformations affect capillary or veins) (40). 


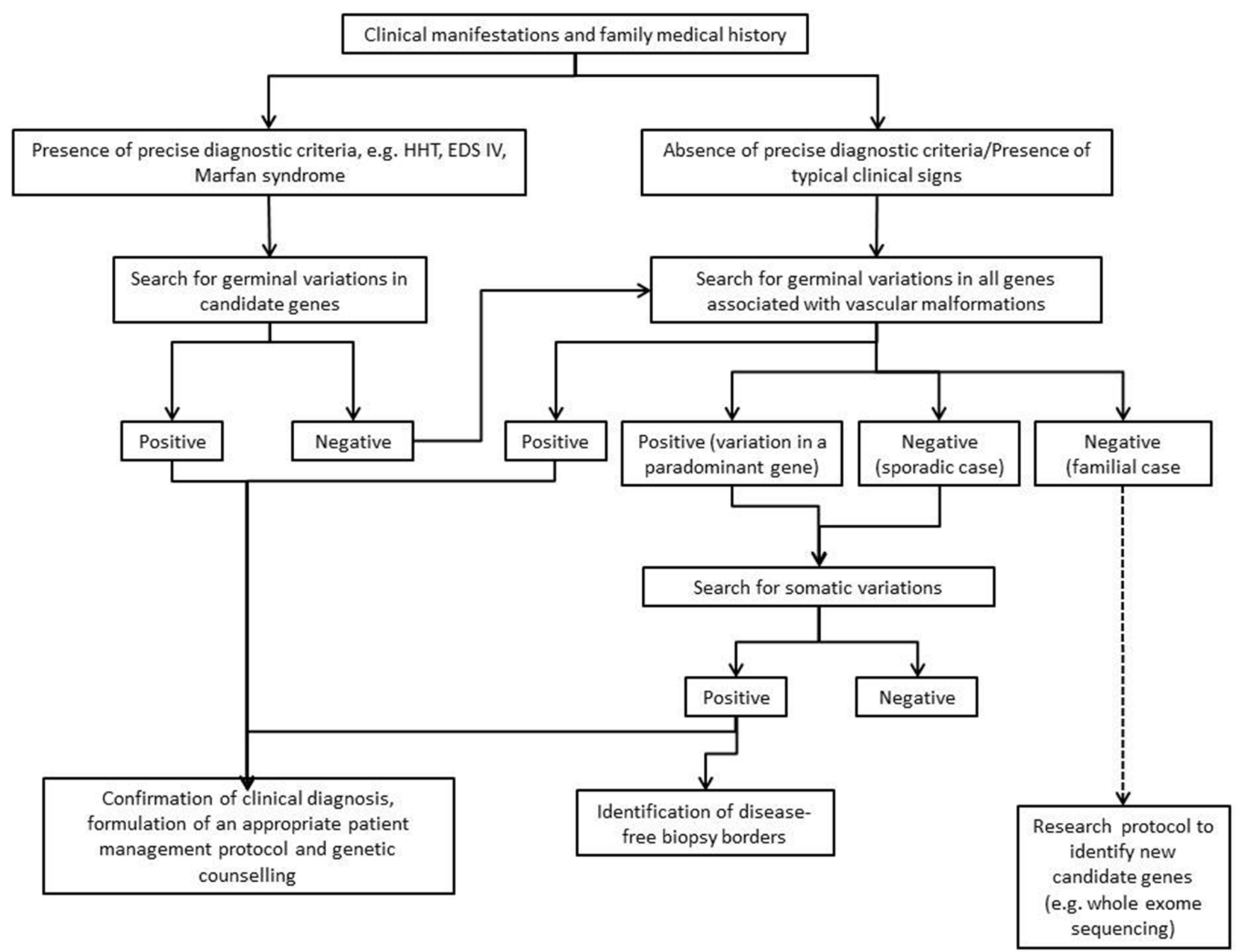

Figure 1. Flow chart of genetic testing for vascular anomalies.

\section{Other likely genes}

SOX17 (OMIM gene 610928), TMEM100 (OMIM gene616334), NOTCH4 (OMIM gene 164951), BMP4 (OMIM gene 112262), BMPR1A (OMIM gene 601299), SMAD5 (OMIM gene 603110), NOTCH3 (OMIM gene 600276), ACTN4 (OMIM gene 604638), BMP10 (OMIM gene 608748), CHST11 (OMIM gene 610128), CHTOP (OMIM gene 614206), DLL4 (OMIM gene 605185), MGP (OMIM gene 154870), MYO9A (OMIM gene 604875), NOTCH1 (OMIM gene 190198), PRRC2B (OMIM gene not available), RBPJ (OMIM gene 147183), SH3PXD2A (OMIM gene not available), SLC20A2 (OMIM gene 158378), SLC25A20 (OMIM gene 613698), FOXF1 (OMIM gene 601089), BMPR2 (OMIM gene 600799).

Pathogenic variants may include missense, nonsense, splicing, small insertions and deletions, small indels, gross insertions, duplications and complex rearrangements.

\section{Aims of the test}

- To determine the gene defect responsible for the disease;

- To confirm clinical diagnosis;

- To assess the recurrence risk and perform genetic counselling for at-risk/affected individuals.

\section{Test characteristics}

\section{Specialist centers/Published guidelines}

The test is listed in the Orphanet database and is offered by 27 accredited medical genetic laboratories in the $\mathrm{EU}$, and in the GTR database, offered by 4 accredited medical genetic laboratories in the US.

Guidelines for clinical use of the test are described in disease-specific chapters of Genetics Home Reference (ghr.nlm. nih.gov) and Gene Reviews (41).

\section{Test strategy}

Clinically distinguishable syndromes can be analyzed by sequencing only those genes known to be associated with that specific disease using Sanger or Next Generation Sequencing (NGS); if the results are negative, or more generally if clinical signs are ambiguous for diagnosis, a multi-gene NGS panel is used to detect nucleotide variations in coding exons and flanking introns of the above genes.

The efficiency of targeted NGS is precious for VAs because of their complex inheritance pattern and genetic and phenotypic heterogeneity. DNA extracted from blood (or saliva) should always be analyzed in tandem with DNA extracted from affected tissues (Fig. 1). In fact, performed in this way, the test 
makes it possible to identify variants specific for the affected tissue and to determine whether the variant is inherited from the parents or occurred as a sporadic somatic event. In a single experiment, it is possible to identify germline pathogenic variants and/or somatic pathogenic variants (an allelic imbalance of $\geq 6 \%$ is the cut-off for a positive test). The results obtained from targeted NGS are analyzed using an in-house bioinformatic tool that compares results obtained from the germinal lineage (blood or saliva specimens) and affected tissue. For variant selection, a cut-off value (related to biopsy and blood results) is used, and if the variant frequency is higher than the cut-off value it is considered for further analysis. The cut-off depends on tissue quality, extraction method, biocomputing software and other parameters. Potentially causative variants and regions with low coverage are Sanger-sequenced. Sanger sequencing is also used for family segregation studies.

Multiplex Ligation Probe Amplification (MLPA) is used to detect duplications and deletions in ABCC6, ACVRL1, CCM2, COL3A1, ENG, FBN1, KRIT1, PDCD10, PTEN, RASA1, SLC2A10, TGFBR1 and TGFB2.

Sporadic cases with negative test outcome or positive results in genes with paradominant inheritance (ANTXR1, CCM2, ENG, GLMN, KDR, KRIT1, PDCD10, PTEN, RASA1 and $T E K)$ should be tested for somatic variations. Potentially causative variants need to be verified by further means (e.g. cloning + Sanger sequencing, Sanger sequencing, minisequencing).

To perform molecular diagnosis, a single sample of biological material is normally sufficient. This may be $1 \mathrm{ml}$ peripheral blood in a sterile tube with $0.5 \mathrm{ml} \mathrm{K}$ EDTA or $1 \mathrm{ml}$ saliva in a sterile tube with $0.5 \mathrm{ml}$ ethanol $95 \%$. Sampling rarely has to be repeated.

A frozen intra-lesional biopsy specimen, in addition to blood or saliva, is necessary to test for somatic variations.

Gene-disease associations and the interpretation of genetic variants are rapidly developing fields. It is therefore possible that the genes mentioned in this note may change as new scientific data is acquired. It is also possible that genetic variants today defined as of "unknown or uncertain significance" may acquire clinical importance.

\section{Genetic test results \\ Positive}

Identification of pathogenic variants in the above genes confirms the clinical diagnosis and is an indication for family studies.

A pathogenic variant is known to be causative for a given genetic disorder based on previous reports or predicted to be causative based on loss of protein function or expected significant damage to protein or protein/protein interactions. In this way it is possible to obtain a molecular diagnosis in new/other subjects, establish the risk of recurrence in family members and plan preventive and/or therapeutic measures.

\section{Inconclusive}

Detection of a variant of unknown or uncertain significance (VUS): a new variation without any evident pathogenic significance or a known variation with insufficient evidence (or with conflicting evidence) to indicate it is likely benign or likely pathogenic for a given genetic disorder. In these cases, it is advisable to extend testing to the patient's relatives to assess variant segregation and clarify its contribution. In some cases, it could be necessary to perform further examinations/tests or to do a clinical reassessment of pathological signs.

\section{Negative}

The absence of variations in the genomic regions investigated does not exclude a clinical diagnosis but suggests the following possibilities

- Alterations that cannot be identified by sequencing, such as large rearrangements that cause loss (deletion) or gain (duplication) of extended gene fragments.

- Sequence variations in genomic regions not investigated by the test, such as regulatory regions, 5'- and 3'-UTR) and deep intronic regions.

- Variations in other genes not investigated by the present test.

\section{Unexpected}

Unexpected results may emerge from the test, for example information regarding consanguinity, absence of family correlation or other genetically-based diseases.

\section{Risk for progeny}

If the identified pathogenic variant has autosomal dominant transmission, the probability that an affected carrier transmit the disease variant to his/her children is $50 \%$ in any pregnancy, irrespective of the sex of the child conceived.

In autosomal recessive mutations, both parents are usually healthy carriers. In this case, the probability of transmitting the disorder to the offspring is $25 \%$ in any pregnancy of the couple, irrespective of the sex of the child. An affected individual generates healthy carrier sons and daughters in all cases, except in pregnancies with a healthy carrier partner. In these cases, the risk of an affected son or daughter is $50 \%$.

De novo somatic variations cannot be inherited or transmitted.

In paradominant inheritance, only the germline genetic variant is transmitted in an autosomal dominant fashion and the probability that carriers transmit the germline pathogenic variant to their children is $50 \%$ in any pregnancy, irrespective of the sex of the child conceived.

\section{Limits of the test}

The test is limited by current scientific knowledge regarding the genes and diseases.

Currently, there is no evidence of a genotype-phenotype correlation between mosaicism level and the severity of clinical manifestation. 
Analytical sensitivity (proportion of positive tests when the genotype is truly present) and specificity (proportion of negative tests when the genotype is not present)

NGS Analytical sensitivity $>99.99 \%$, with a minimum coverage of 10X; Analytical specificity $99.99 \%$.

SANGER Analytical sensitivity $>99.99 \%$; Analytical specificity $99.99 \%$.

MINISEQUENCING Analytical sensitivity $>99.99 \%$; Analytical specificity $99.99 \%$.

MLPA Analytical sensitivity $>99.99 \%$; Analytical specificity $99.99 \%$.

\section{Clinical sensitivity (proportion of positive tests} if the disease is present) and clinical specificity (proportion of negative tests if the disease is not present)

The variations in the aforementioned genes depend closely on the specific disorder. Clinical sensitivity and specificity, based on current genetic knowledge and internal case studies, can be estimated at $20-30 \%$ and $99.78 \%$, respectively (42).

No epidemiological data is available for private variants (specific to one or very few families). In such cases, clinical sensitivity is estimated on the basis of internal case studies (42).

\section{Prescription appropriateness}

The genetic test is appropriate when:

a) the patient meets the diagnostic criteria for Vas (43);

b) the sensitivity of the test is greater than or equal to that of tests described in the literature.

\section{Clinical utility}

\begin{tabular}{|l|c|}
\hline Clinical management & Utility \\
\hline Confirmation of clinical diagnosis & Yes \\
\hline Differential diagnosis & Yes \\
\hline Couple risk assessment & Yes \\
\hline
\end{tabular}

Availability of clinical trials can be checked on-line at https://clinicaltrials.gov/

\section{References}

1. Duffy K. Genetics and syndromes associated with vascular malformations. Pediatr Clin North Am 2010; 57(5): 1111-20.

2. Happle R. Lethal genes surviving by mosaicism a possible explanation for sporadic birth defects involving the skin. J Am Acad Dermatol 1987; 16(4): 899-06.

3. Amyere $M$, Aerts V, Brouillard P, McIntyre BA, Duhoux FP, Wassef $M$, Enjolras O, Mulliken JB, Devuyst O, Antoine-Poirel H, Boon LM, Vikkula M. Somatic uniparental isodisomy explains multifocality of glomuvenous malformations. Am J Hum Genet 2013; 92(2): 188-96.

4. Mulliken JB. Vascular birthmarks in folklore, history, art, and literature. In Mulliken JB, Young AE, editors. Vascular birthmarks Hemangiomas and malformations 1988. Philadelphia, Pa WB Saunders Company 3-23.

5. Jinnin M, Medici D, Park L, Limaye N, Liu Y, Boscolo E, Bischoff J,
Vikkula M, Boye E, Olsen BR. Suppressed NFAT-dependent VEGFR1 expression and constitutive VEGFR2 signaling in infantile hemangioma. Nat Med 2008; 14(11): 1236-46.

6. Walter JW, North PE, Waner M, Mizeracki A, Blei F, Walker JW, Reinisch JF, Marchuk DA. Somatic mutation of vascular endothelial growth factor receptors in juvenile hemangioma. Genes Chromosomes Cancer 2002; 33(3): 295-303.

7. Ayturk UM, Couto JA, Hann S, Mulliken JB, Williams KL, Huang AY, Fishman SJ, Boyd TK, Kozakewich HP, Bischoff J, Greene AK, Warman ML. Somatic activating mutations in GNAQ and GNA11 are associated with congenital hemangioma. Am J Hum Genet 2016; 98(4): 789-95.

8. Lim YH, Bacchiocchi A, Qiu J, Straub R, Bruckner A, Bercovitch L, Narayan D; Yale Center for Mendelian Genomics, McNiff J, Ko C, Robinson-Bostom L, Antaya R, Halaban R, Choate KA. GNA14 somatic mutation causes congenital and sporadic vascular tumors by MAPK activation. Am J Hum Genet 2016; 99(2): 443-50.

9. Couto JA, Vivero MP, Kozakewich HP, Taghinia AH, Mulliken JB, Warman ML, Greene AK. A somatic MAP3K3 mutation is associated with verrucous venous malformation. Am J Hum Genet 2015; 96(3): 480-6.

10. Groesser L, Peterhof E, Evert M, Landthaler M, Berneburg M, Hafner C. BRAF and RAS Mutations in Sporadic and Secondary Pyogenic Granuloma. J Invest Dermatol 2016; 136(2):481-6.

11. Soblet J, Limaye N, Uebelhoer M, Boon LM, Vikkula M. Variable somatic TIE2 mutations in half of sporadic venous malformations. Mol Syndromol 2013; 4(4): 179-183.

12. Castel P, Carmona FJ, Grego-Bessa J, Berger MF, Viale A, Anderson KV, Bague S, Scaltriti M, Antonescu CR, Baselga E, Baselga J. Somatic PIK3CA mutations as a driver of sporadic venous malformations. Sci Transl Med. 2016; 8(332): 332ra42.

13. Brouillard $\mathrm{P}$, Boon LM, Mulliken JB, Enjolras O, Ghassibé M, Warman ML, Tan OT, Olsen BR, Vikkula M. Mutations in a novel factor, glomulin, are responsible for glomuvenous malformations ('glomangiomas'). Am J Hum Genet 2002 Apr; 70(4): 866-74.

14. Akers AL, Johnson E, Steinberg GK, Zabramski JM, Marchuk DA. Biallelic somatic and germline mutations in cerebral cavernous malformations (CCMs) evidence for a two-hit mechanism of CCM pathogenesis. Hum Mol Genet 2009; 18(5): 919-930.

15. Gault J, Awad IA, Recksiek P, Shenkar R, Breeze R, Handler M, Kleinschmidt-DeMasters BK. Cerebral cavernous malformations somatic mutations in vascular endothelial cells. Neurosurgery 2009; 65(1): 138-44; discussion 144-5.

16. McDonald DA, Shi C, Shenkar R, Gallione CJ, Akers AL, Li S, De Castro N, Berg MJ, Corcoran DL, Awad IA, Marchuk DA. Lesions from patients with sporadic cerebral cavernous malformations harbor somatic mutations in the CCM genes evidence for a common biochemical pathway for CCM pathogenesis. Hum Mol Genet 2014; 23(16): 4357-70.

17. Soblet J, Kangas J, Nätynki M, Mendola A, Helaers R, Uebelhoer M, Kaakinen M, Cordisco M, Dompmartin A, Enjolras O, Holden S, Irvine AD, Kangesu L, Léauté-Labrèze $C$, Lanoel A, Lokmic $Z$, Maas S, McAleer MA, Penington A, Rieu P, Syed S, van der Vleuten C, Watson R, Fishman SJ, Mulliken JB, Eklund L, Limaye N, Boon LM, Vikkula M. Blue rubber bleb nevus (BRBN) syndrome is caused by somatic TEK (TIE2) mutations. J Invest Dermatol 2017;137(1): 20716.

18. Couto JA, Ayturk UM, Konczyk DJ, Goss JA, Huang AY, Hann S, Reeve JL, Liang MG, Bischoff J, Warman ML, Greene AK. A somatic GNA11 mutation is associated with extremity capillary malformation and overgrowth. Angiogenesis 2017; 20(3): 303-306.

19. Shirley MD, Tang H, Gallione CJ, Baugher JD, Frelin LP, Cohen B, North PE, Marchuk DA, Comi AM, Pevsner J. Sturge-Weber syndrome and port-wine stains caused by somatic mutation in GNAQ. N Engl J Med 2013; 368(21): 1971-1979.

20. Revencu N, Boon LM, Mendola A, Cordisco MR, Dubois J, Clapuyt P, Hammer F, Amor DJ, Irvine AD, Baselga E, Dompmartin A, Syed S, Martin-Santiago A, Ades L, Collins F, Smith J, Sandaradura S, Barrio VR, Burrows PE, Blei F, Cozzolino M, Brunetti-Pierri N, Vicente A, Abramowicz M, Désir J, Vilain C, Chung WK, Wilson A, Gardiner CA, Dwight Y, Lord DJ, Fishman L, Cytrynbaum C, Chamlin S, Ghali F, Gilaberte Y, Joss S, Boente Mdel C, Léauté-Labrèze C, Delrue MA, 
Bayliss S, Martorell L, González-Enseñat MA, Mazereeuw-Hautier J, O'Donnell B, Bessis D, Pyeritz RE, Salhi A, Tan OT, Wargon O, Mulliken JB, Vikkula M. RASA 1 mutations and associated phenotypes in 68 families with capillary malformation-arteriovenous malformation. Hum Mutat 2013; 34(12): 1632-41.

21. Uchiyama $Y$, Nakashima M, Watanabe S, Miyajima M, Taguri M, Miyatake S, Miyake N, Saitsu H, Mishima H, Kinoshita A, Arai H, Yoshiura K, Matsumoto N. Ultra-sensitive droplet digital PCR for detecting a low-prevalence somatic GNAQ mutation in Sturge-Weber syndrome. Sci Rep 2016; 6: 22985.

22. Amyere M, Revencu N, Helaers R, Pairet E, Baselga E, Cordisco M, Chung W, Dubois J, Lacour JP, Martorell L, Mazereeuw-Hautier J, Pyeritz RE, Amor DJ, Bisdorff A, Blei F, Bombei H, Dompmartin A Brooks D, Dupont J, González-Enseñat MA, Frieden I, Gérard M, Kvarnung $M$, Hanson-Kahn AK, Hudgins $L$, Léauté-Labrèze $C, M c-$ Cuaig C, Metry D, Parent P, Paul C, Petit F, Phan A, Quere I, Salhi A, Turner A, Vabres P, Vicente A, Wargon O, Watanabe S, Weibel L, Wilson A, Willing M, Mulliken JB, Boon LM, Vikkula M. Germline lossof-function mutations in EPHB4 cause a second form of capillary malformation-arteriovenous malformation (CM-AVM2) deregulating RAS-MAPK signaling. Circulation 2017; 136(11): 1037-1048.

23. Best DH, Vaughn C, McDonald J, Damjanovich K, Runo JR, Chibuk JM, Bayrak-Toydemir P. Mosaic ACVRL1 and ENG mutations in hereditary haemorrhagic telangiectasia patients. J Med Genet 2011; 48(5): 358-60.

24. Hernandez F, Huether R, Carter L, Johnston T, Thompson J, Gossage JR, Chao E, Elliott AM. Mutations in RASA1 and GDF2 identified in patients with clinical features of hereditary hemorrhagic telangiectasia. Hum Genome Var 2015; 2: 15040.

25. Gallione $\mathrm{CJ}$, Richards JA, Letteboer TG, Rushlow D, Prigoda NL, Leedom TP, Ganguly A, Castells A, Ploos van Amstel JK, Westermann CJ, Pyeritz RE, Marchuk DA. SMAD4 mutations found in unselected HHT patients. J Med Genet 2006; 43(10): 793-7.

26. Luks VL, Kamitaki N, Vivero MP, Uller W, Rab R, Bovée JV, Rialon KL, Guevara CJ, Alomari Al, Greene AK, Fishman SJ, Kozakewich HP, Maclellan RA, Mulliken JB, Rahbar R, Spencer SA, Trenor CC 3rd, Upton J, Zurakowski D, Perkins JA, Kirsh A, Bennett JT, Dobyns WB, Kurek KC, Warman ML, McCarroll SA, Murillo R. Lymphatic and other vascular malformative overgrowth disorders are caused by somatic mutations in PIK3CA. J Pediatr 2015; 166(4): 1048-54.e1-5.

27. Pansuriya TC, van Eijk R, d'Adamo P, van Ruler MA, Kuijjer ML, Oosting J, Cleton-Jansen AM, van Oosterwijk JG, Verbeke SL, Meijer D, van Wezel T, Nord KH, Sangiorgi L, Toker B, Liegl-Atzwanger B, San-Julian M, Sciot R, Limaye N, Kindblom LG, Daugaard S, Godfraind C, Boon LM, Vikkula M, Kurek KC, Szuhai K, French PJ, Bovée JV. Somatic mosaic IDH1 and IDH2 mutations are associated with enchondroma and spindle cell hemangioma in Ollier disease and Maffucci syndrome. Nat Genet 2011; 43(12): 1256-61.

28. Lindhurst MJ, Sapp JC, Teer JK, Johnston JJ, Finn EM, Peters K, Turner J, Cannons JL, Bick D, Blakemore L, Blumhorst C, Brockmann K, Calder P, Cherman N, Deardorff MA, Everman DB, Golas G, Greenstein RM, Kato BM, Keppler-Noreuil KM, Kuznetsov SA, Miyamoto RT, Newman K, Ng D, O'Brien K, Rothenberg S, Schwartzentruber DJ, Singhal V, Tirabosco R, Upton J, Wientroub S, Zackai EH, Hoag K, Whitewood-Neal T, Robey PG, Schwartzberg PL, Darling TN Tosi LL, Mullikin JC, Biesecker LG. A mosaic activating mutation in AKT1 associated with the Proteus syndrome. N Engl J Med; 365(7): 611-9.

29. Loeys BL, Schwarze U, Holm T, Callewaert BL, Thomas GH, Pannu $\mathrm{H}$, De Backer JF, Oswald GL, Symoens S, Manouvrier S, Roberts AE, Faravelli F, Greco MA, Pyeritz RE, Milewicz DM, Coucke PJ, Cameron DE, Braverman AC, Byers PH, De Paepe AM, Dietz HC. Aneurysm syndromes caused by mutations in the TGF- $\beta$ receptor. $N$ Engl J Med 2006; 355(8): 788-98.

30. Lindsay ME, Schepers D, Bolar NA, Doyle JJ, Gallo E, Fert-Bober J, Kempers MJ, Fishman EK, Chen Y, Myers L, Bjeda D, Oswald G, Elias AF, Levy HP, Anderlid BM, Yang MH, Bongers EM, Timmermans J, Braverman AC, Canham N, Mortier GR, Brunner HG, Byers PH, Van Eyk J, Van Laer L, Dietz HC, Loeys BL. Loss-of-function mutations in TGFB2 cause a syndromic presentation of thoracic aortic aneurysm. Nat Genet. 2012; 44(8): 922-7.

31. Wischmeijer A, Van Laer L, Tortora G, Bolar NA, Van Camp G,
Fransen E, Peeters N, di Bartolomeo R, Pacini D, Gargiulo G, Turci S, Bonvicini M, Mariucci E, Lovato L, Brusori S, Ritelli M, Colombi M, Garavelli L, Seri M, Loeys BL. Thoracic aortic aneurysm in infancy in aneurysms-osteoarthritis syndrome due to a novel SMAD3 mutation further delineation of the phenotype. Am J Med Genet A 2013; 161A(5): 1028-35.

32. Frank M, Albuisson J, Ranque B, Golmard L, Mazzella JM, Bal-Theoleyre L, Fauret AL, Mirault T, Denarié N, Mousseaux E, Boutouyrie $P$, Fiessinger JN, Emmerich J, Messas E, Jeunemaitre X. The type of variants at the COL3A1 gene associates with the phenotype and severity of vascular Ehlers-Danlos syndrome. Eur J Hum Genet 2015; 23(12): 1657-64.

33. Ritelli $M$, Chiarelli $N$, Dordoni $C$, Reffo $E$, Venturini $M$, Quinzani $S$, Monica MD, Scarano G, Santoro G, Russo MG, Calzavara-Pinton P, Milanesi $\mathrm{O}$, Colombi M. Arterial tortuosity syndrome homozygosity for two novel and one recurrent SLC2A10 missense mutations in three families with severe cardiopulmonary complications in infancy and a literature review. BMC Med Genet 2014; 15: 122.

34. Orloff MS, He X, Peterson C, Chen F, Chen JL, Mester JL, Eng C. Germline PIK3CA and AKT1 mutations in Cowden and Cowdenlike syndromes. Am J Hum Genet 2013; 92(1): 76-80.

35. Zhou X, Hampel H, Thiele H, Gorlin RJ, Hennekam RC, Parisi M, Winter RM, Eng C. Association of germline mutation in the PTEN tumour suppressor gene and Proteus and Proteus-like syndromes. Lancet 2001; 358(9277): 210-1.

36. Baetens M, Van Laer L, De Leeneer K, Hellemans J, De Schrijver J, Van De Voorde H, Renard M, Dietz H, Lacro RV, Menten B, Van Criekinge W, De Backer J, De Paepe A, Loeys B, Coucke PJ. Applying massive parallel sequencing to molecular diagnosis of Marfan and Loeys-Dietz syndromes. Hum Mutat 2011; 32(9): 1053-62.

37. Nitschke Y, Baujat G, Botschen U, Wittkampf T, du Moulin M, Stella J, Le Merrer M, Guest G, Lambot K, Tazarourte-Pinturier MF, Chassaing N, Roche O, Feenstra I, Loechner K, Deshpande C, Garber SJ, Chikarmane R, Steinmann B, Shahinyan T, Martorell L, Davies J, Smith WE, Kahler SG, McCulloch M, Wraige E, Loidi L, Höhne W, Martin L, Hadj-Rabia S, Terkeltaub R, Rutsch F. Generalized arterial calcification of infancy and pseudoxanthoma elasticum can be caused by mutations in either ENPP1 or ABCC6. Am J Hum Genet 2012; 90(1): 25-39.

38. McDonell LM, Mirzaa GM, Alcantara D, Schwartzentruber J, Carter MT, Lee LJ, Clericuzio CL, Graham JM Jr, Morris-Rosendahl DJ, Polster T, Acsadi G, Townshend S, Williams S, Halbert A, Isidor B, David A, Smyser CD, Paciorkowski AR, Willing M, Woulfe J, Das S, Beaulieu CL, Marcadier J; FORGE Canada Consortium, Geraghty MT, Frey BJ, Majewski J, Bulman DE, Dobyns WB, O'Driscoll M, Boycott KM. Mutations in STAMBP, encoding a deubiquitinating enzyme, cause microcephaly-capillary malformation syndrome. Nat Genet 2013; 45(5): 556-62.

39. Couto JA, Huang AY, Konczyk DJ, Goss JA, Fishman SJ, Mulliken $\mathrm{JB}$, Warman ML, Greene AK. Somatic MAP2K1 mutations are associated with extracranial arteriovenous malformation. Am J Hum Genet 2017; 100(3): 546-54.

40. Cetinkaya A, Xiong JR, Vargel I, Kösemehmetoğlu K, Canter Hi, Gerdan ÖF, Longo N, Alzahrani A, Camps MP, Taskiran EZ, Laupheimer S, Botto LD, Paramalingam E, Gormez Z, Uz E, Yuksel B, Ruacan Ş, Sağıroğlu MŞ, Takahashi T, Reversade B, Akarsu NA. Loss-of-function mutations in ELMO2 cause intraosseous vascular malformation by impeding RAC1 signaling. Am J Hum Genet 2016; 99(2): 299-317.

41. Pagon RA, Adam MP, Ardinger HH, Wallace SE, Amemiya A, et al. (2016) GeneReviews http//www.ncbi.nlm.nih.gov/pubmed/20301295

42. Centers for disease control and prevention (CDC) (2009) Good laboratory practices for molecular genetic testing for heritable diseases and conditions. Mmwr 581-37.

43. Stillo $F$, Baraldini V, Dalmonte $P$, El Hachem $M$, Mattassi R, Vercellio G, Amato B, Bellini C, Bergui M, Bianchini G, Diociaiuti A, Campisi C, Gandolfo C, Gelmetti C, Moneghini L, Monti L, Magri C, Neri I, Paoloantonio G, Patrizi A, Rollo M, Santecchia L, Vaghi M, Vercellino N; Italian Society for the study of Vascular Anomalies (SISAV). Vascular Anomalies Guidelines by the Italian Society for the study of Vascular Anomalies (SISAV). Int Angiol 2015; 34(2 Suppl 1): 1-4. 